\title{
Adatok, tendenciák és elméletek a parafenilén-diamin szenzibilizációról
}

\section{Data, trends and theories about the paraphenylene diamine hypersensitivity}

\author{
PÓNYAI GYÖRGYI DR., DICZIG BRIGITTE, NÉMETH ILONA, \\ TEMESVÁRI ERZSÉBET DR.
}

Semmelweis Egyetem Bőr-Nemikórtani és Bőronkológiai Klinika, Budapest

\section{ÖSSZEFOGLALÁS}

A parafenilén-diamin (PPD) erös allergén, börrel érintkezve dermatitist, Quincke oedemát válthat ki, szisztémásan pedig mérgező. A hajfestékek használatát szigorúan szabályozzák, ezáltal a PPD érzékeny páciensek száma csökkent. Ezzel párhuzamosan azonban megjelent a PPD új expozíciós forrása, a fekete hennatetoválás. Ezen börfesték PPD koncentrációja igen magas lehet. Az ideiglenes tetoválások leginkább a fiatal korosztályokat érintik.

A vizsgálatunkban szereplő öt év epicutan tesztelt betegei között a PPD szenzibilizálódás 6,22\%-os elöfordulása az európai irodalmi adatokhoz képest magasabb. Annak ellenére, hogy a PPD érzékeny betegek száma csökkent, feltünö, hogy öt év lefolyása alatt a betegek életkor szerinti megoszlása változott: 2011-re már a 30as, 40-es korosztály volt többségben és a hajszínezés által kiváltott adverz reakciók egyre fiatalabb betegeknél léptek fel. A PPD-szenzibilizáció számos hosszú távú következménnyel jár, melyek jelentősen befolyásolják az érintett személyek életét. Foglalkozás szempontjából ki kell emelni a fodrászokat, hiszen ök vannak leginkább kitéve a hajszínezókkel való expozíciónak már tanulókoruk óta.

Kulcsszavak:

parafenilén-diamin - kontakt szenzibilizáció hajfestés - tetoválás

\section{SUMMARY}

Paraphenylene-diamine (PPD) is a potent, common contact allergen. Skin exposure to PPD might include dermatitis or Quincke oedema, while ingestion of the chemical causes systemic poisoning. The concentration of $P P D$ in hairdyes is restricted in the European Union. Although the strict legislation led to a decreased number of PPD hypersensitive patients, a new source of PPD exposure has appeared: the black henna tattoos.

The concentration of PPD in these tattoos can be extremely high. Henna tattoos are mostly popular among children and adolescents.

In our study the prevalance of PPD senzitization among patients patch tested between 2007 and 2012 was 6,22\%, a remarkably high value compared to data published in the literature.

Although the number of PPD hypersensitive patients has decreased over these years, we detected an outstanding change in the distribution of age groups among sensitized patients: in 2010-2011 adverse reactions to hairdyes were observed at a much younger age than in the previous years.

PPD hypersensitivity has a significat impact on patients' lives, affecting daily routines and limiting career options. Occupational exposure to PPD is still one of the most important risk factors, since hairdressers are chronically exposed to a large number of chemicals, including hairdyes.

\section{Key words: \\ paraphenylene diamine hypersensitivity - hairdyes - black henna}

A hajfestékek használata több évezredes múltra tekint vissza, ez idő alatt a színezőanyagok alapanyaga és összetétele, valamint az alkalmazás módja is változott. A parafenilén-diamin (PPD) 1863-as felfedezését követően in- dult meg a napjainkban is használt oxidációs, tartós hajfestékek gyártása. A hajfestékek által okozott adverz reakciókat leginkább e csoport tagjainak használatát követően tapasztalják, ebben a legfontosabb szerepet a PPD játssza.

Levelező szerző: Dr. Pónyai Györgyi, SE Bőrklinika, 1085 Budapest, Mária u. 41.

e-mail: gyorgyi.ponyai@gmail.com 
A szenzibilizálódás hosszú távú következményei befolyásolják a betegek életminőségét, mivel a PPD-hez hasonló kémiai szerkezetû anyagok keresztreakciót indíthatnak be. Az allergén jelentőségét bizonyítja, hogy a Dermatitis folyóirat 2006-ban a PPD-t az ,év allergénjének” választotta (1).

A henna eredetileg a keleti kultúrákban vallási és rituális okból használt festékanyag, a szó a Lawsonia (inermis, alba) nevű cserje arab megnevezéséből ered (2-5). Bôrre való felvitelhez a cserje leveleit porlasztják, és különféle hozzáadott anyagok segítségével pasztává alakítják (4). Természetes henna által kiváltott adverz reakciók rendkívül ritkák, ezeket leginkább a hozzáadott vegyületek, például a PPD okozzák $(6,7)$.

\section{Betegek és módszerek}

A Semmelweis Egyetem Bőr-, Nemikórtani és Bőronkológiai Klinika Allergológiai Szakrendelésén 2007. január és 2012. január között BrialGmbh (D-Greven) környezeti alapsorozattal epicutan tesztelt, 2445 beteg eredményeinek retrospektív analízise során a PPD szenzibilizáció előfordulását vizsgáltuk, meghatározva annak életkor, nem és diagnózis szerinti megoszlását.

Az epicutan tesztelésre a betegek tünetmentes állapotában került sor. A teszt elvégzésének kizáró kritériumai közé tartozott a lokális szteroid használat a vizsgálatot megelőző egy hétben, a teszt elvégzése előtt egy héttel és a teszt ideje alatt szedett antihisztamin, illetve szisztémás szteroid kezelés, UV sugárzás a vizsgálatot megelőzó hat hétben, akut, vagy aktív bőrtünetek, aktív rhinitis, terhesség, szoptatás. Az epicutan tesztelés nemzetközileg ellenőrzött és elfogadott koncentrációjú, nem irritáló, vivőanyagban oldott allergének felhasználásával történt (1. táblázat). Az antigén felhelyezése tünetmentes hátbőrre történt, 48 órás okklúzióban. Az értékelés a 20., 40. (szükség esetén 60.) percben, majd a 48., 72., 96. órában és a 7. napon történt (1. ábra).

\section{Eredmények}

A 2445 tesztelt beteg közül 152 bizonyult PPD érzékenynek (6,22\%). A 152 PPD érzékeny beteg 75\%-a (114 fő) nő volt, $25 \%$ férfi (38 fó). A betegeket hét korcsoportba soroltuk: 5-14 év, 15-24 év, 25-34 év, 35-44 év, 45-54 év, 55-64 év, illetve 65-74 év.

2007-ben a PPD érzékeny betegek többsége 60 év körüli volt. Később a fiatalabb korosztályok aránya évről

\begin{tabular}{|l|l|l|}
\hline Neomycinsulfat & Mercaptobenzothiazol (MBT) & Resorcin \\
Benzocain & Kolofónium & Propolis \\
Jodchloroxychinolin & Pix / Fakátrány & P-tert-buthylphenol- \\
Paraben & Perubalzsam & formaldehyd \\
Lanolin & Terpentin & Fragrance mix I. \\
Primin & Paraphenyldiamin (PPD) & Higanyklorid \\
Sesquiterpenlacton & IPPD & (Hg-klorid) \\
Phenylbutazon & Higany (II)amidochloratum & Epoxy gyanta \\
Króm & Formalin & Budesonid \\
Nikkel (II) sulfat & Propylenglycol & Tixocortol-privalat \\
Kobaltklorid (Co) & Thiomersal & Methyldibromo-glutaronitril \\
Tetramethylthiuramdisulfid & Quaternium & Fragrance mix II. \\
(TMTD) & Kathon CG & \\
\hline
\end{tabular}

1. táblázat

Standard epicutan sor (Brial-AllergenD-Greven)

évre nőtt: 2010-ben a 40-es, 2011-ben pedig már a 3040-es korcsoport dominált. A PPD érzékeny betegek száma ugyan fokozatosan csökkent (2007-ben 65, 2008ban 34, 2009-ben 22, 2010-ben 15, 2011-ben 16 fô), azonban a szenzibilizáció egyre fiatalabb korban jelentkezett (2., 3. ábra).

A diagnosztikus megoszlást tekintve a leggyakoribb a kontakt ekzema volt $(78 \%, 118 / 152)$, ezt követte az atópiás dermatitis (AD) $(8 \%)$, a psoriasis $(5 \%)$, a dyshidrosis (4\%) és a perioralis dermatitis $(2 \%)$ illetve a chronicus vénás insufficiencia $(2 \%)$.

A 152 PPD érzékeny beteg közül 36 $(23,7 \%)$ kapcsolatba hozható bőr- és hajszínező eljárással, anamnézisük, illetve tünetek lokalizációja alapján (a tüneteket megelőző haj-, szemöldök, szempilla festés, fodrász szakma). Közülük harmincnégyen nôk, ketten férfiak voltak. Mindkét férfibeteg fodrász volt és fiatal életkorú (18 és 20 éves). Henna által kiváltott adverz reakció egy esetben fordult elő, henna- 


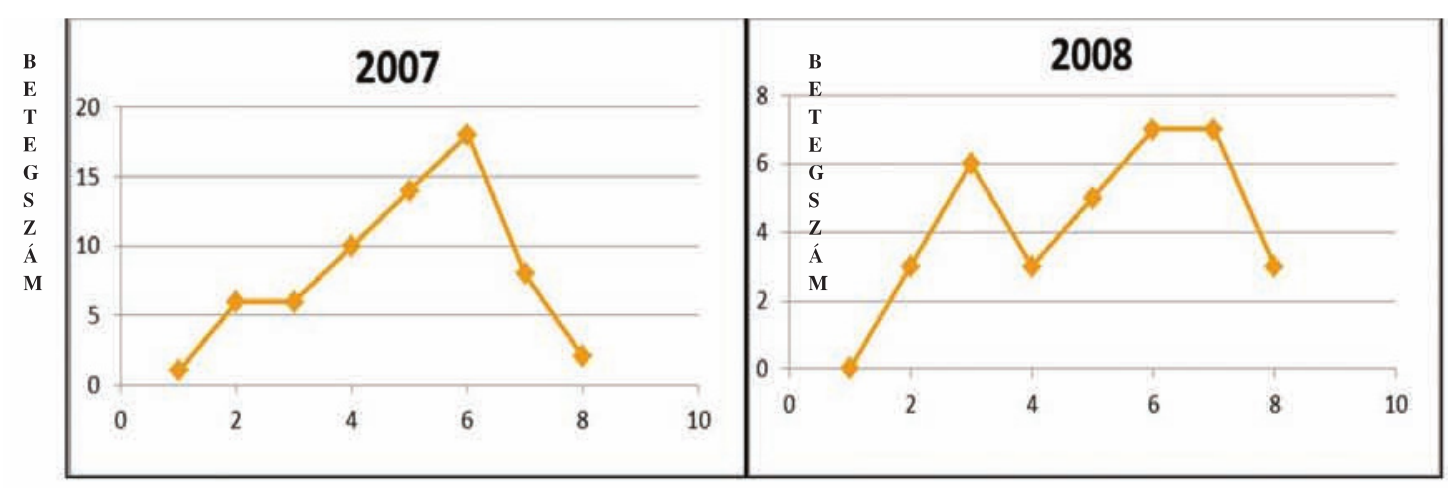

ÉVTIZEDBEN MEGADOTT ÉLETKOR

ÉVTIZEDBEN MEGADOTT ÉLETKOR

2/a. PPD szenzibilizáltak életkor szerinti

2/b. PPD szenzibilizáltak életkor szerinti megoszlása 2007-ben megoszlása 2008-ban

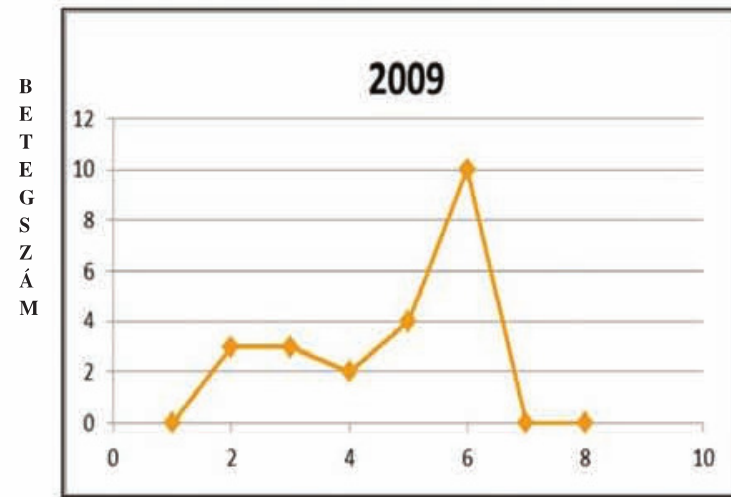

ÉVTIZEDBEN MEGADOTT ÉLETKOR

2/c. PPD szenzibilizáltak életkor szerinti megoszlása 2009-ben

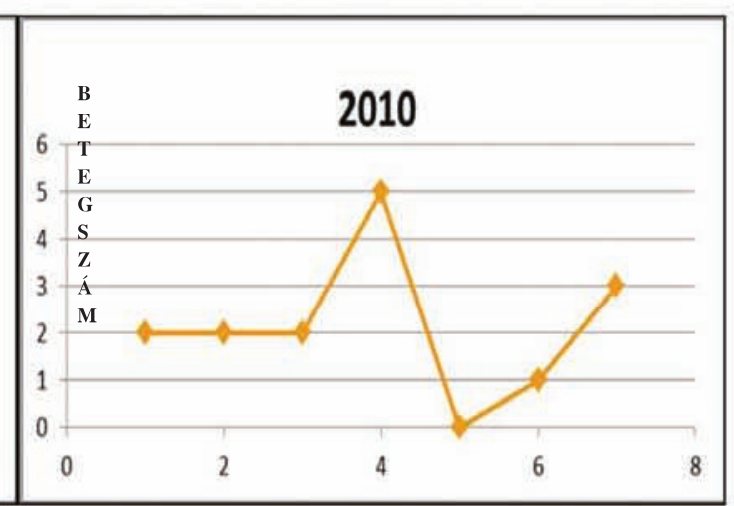

ÉVTIZEDBEN MEGADOTT ÉLETKOR

2/d. PPD szenzibilizáltak életkor szerinti megoszlása 2010-ben

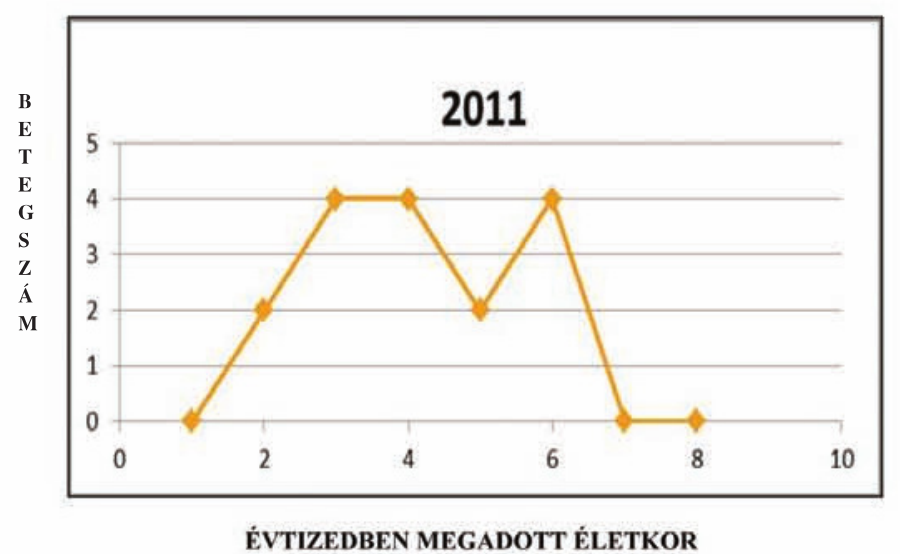

2/e. PPD szenzibilizáltak életkor szerinti megoszlása 2011-ben

$$
\text { 2. ábra }
$$

A PPD szenzibilizáltak életkor szerint megoszlása 
hajfesték használatát követően. Arról nem találtunk adatot, hogy a betegek múltjában előfordult-e ideiglenes hennatetoválás.

A tünetek lokalizációja az expozíciónak megfelelően a következő gyakorisági sorrendben fordult elő: hajas fejbőr dermatitis (12/36), Quincke oedema arcon (10/36), periorbitalis dermatitis (5/36), kontakt urticaria a kézen és a hajas fejbőrön (3/36), periorbitalis kontakt urticaria (1/36) (4., 5.ábra). Ezen kívül három beteg fejbőr, egy pedig kézviszketésról számolt be, utóbbi fodrász volt. Típusos lokalizáció a tarkó (2/36) és a kéz (2/36) is, előbbi esetben hajfestést követő kontakt ekzemáról, utóbbiban foglalkozási expozíció következményes dermatitisérôl volt szó. Egy esetben Köbner-reakció is kialakult hajfestést követően a hajvonalban, illetve a lelógó haj következtében deréktájon, egy discoid lupus erythematodeses női betegnél.

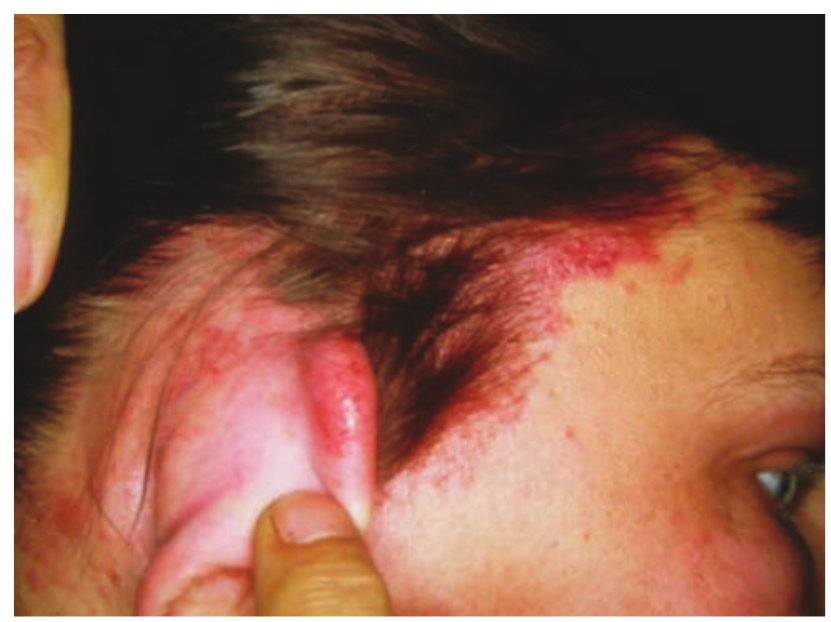

4. ábra

Hajfesték által kiváltott kontakt ekzema a fejbőrön, a hajvonalnál és a fülkagylókon

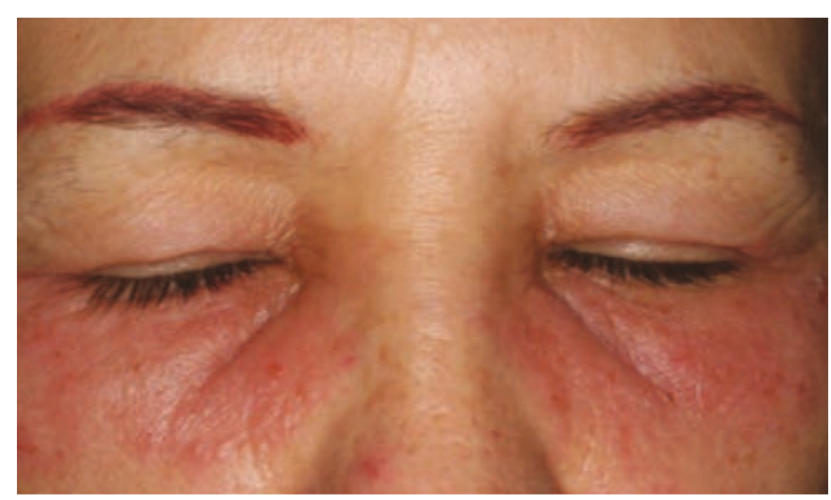

5. ábra

Tartós szemöldök- és szempillafestés által kiváltott periorbitalis dermatitis

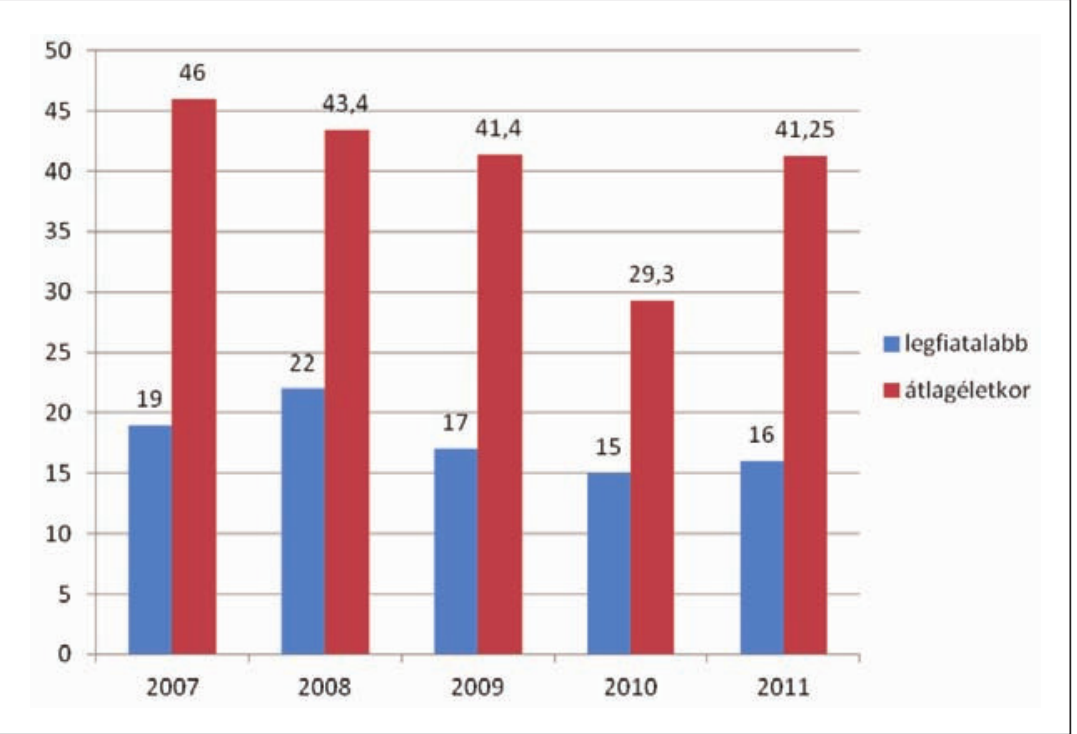

3. ábra

Átlagéletkor és a legfiatalabb szenzibilizáltak életkora

Kiemelendő, hogy a betegek évről évre egyre fiatalabbak voltak. 2007-ben az átlagéletkor 46 év, majd 2011ben már 41,25 év volt. Míg 2007-ben 19 éves volt a legfiatalabb beteg aki hajfesték expozíció által szenzibilizálódott, addig 2010-ben 15 éves, 2011-ben pedig 16 éves.

\section{Megbeszélés}

A parafenilén-diamin kémiai szerkezetét tekintve aromás amin. A vegyület megtalálható szőrme-, textil-, múanyag és nyomdafestékekben, röntgenfilm-előhívó oldatokban, tintában, olajokban, gumi-kemikáliákban. A PPD expozíció legfőbb forrása a hajfesték, ezért ez szenzibilizáció szempontjából nagy rizikót jelent (2, 3-8, 10-13, 16). Különösen veszélyeztetettek a gyermekek illetve kamaszkorúak $(9,13,16)$, körükben gyakori a nyaralások alkalmával a bőrre felvitt hennatetoválás, illetve az egyre fiatalabb korban történő hajfestés. A festék-keverékek tartalmazhatnak még gumi alapú vegyületeket, azoszínezékeket, illetve fémeket (nikkel, kobalt) is. A PPD szenzibilizáció mértéke függ az elsô kontaktus során a bőrre kerülô dózistól (13). A PPD erôs szenzibilizáló képességéhez egy kifejezett irritáló hatás is párosul, mely a festék kimosásakor felszabaduló ammóniának tudható be (17).

A henna az indiai és arab kultúrából közel ezer éve ismert festékanyag, melyet a haj és a körmök színezésére használnak. A gyógyászatban kivonatát antimikotikus, antituberkulotikus és UVA blokkoló hatásai miatt alkalmazzák (4). Aktív hatóanyaga a 2-hidroxi-1,4-naftokinon (2). A henna a Lawsonia inermis alba nevú cserje arab megnevezése $(2,8,14)$, melynek leveleit szárítják, porlasztják, majd a kapott port illóolajokkal (citrom, eukaliptusz és szegfűszeg olaj), ecettel és egyéb természetes festékanyagokkal (tea, kávé) elegyítik (4). Az eredmény egy paszta, melyet a bőrre történő felvitel után több órán át meleg, nedves környezetben száradni hagynak. Minél tovább marad a henna a bőrön, annál sötétebb színt eredményez (4). 
Természetes, tiszta henna által kiváltott adverz reakció rendkívül ritka. Az 1990-es évek óta az ideiglenes tetoválásra adott reakciókról szóló közlések száma azonban jelentősen megnövekedett. Ennek hátterében valószínúleg az újonnan megjelent ,fekete henna” áll, mely az alapvetôen vörösesbarna színú hennához adott egyéb vegyületek eredménye. Ilyen például a PPD, mellyel az ideiglenes tetoválás színe sötétebbé válik, hosszabb ideig marad a bőrön, és felviteli ideje is jelentôsen csökken. A PPD koncentrációja a fekete hennában akár $15,7 \%$ is lehet, ami jóval magasabb a hajszínező anyagokban megengedettnél. A henna tetoválások szabályozása még nem megoldott, a hosszú távú következmények még beláthatatlanok $(2,3,5$, $6,8,11,12,14,15)$.

A hennatetoválások által kiváltott túlérzékenységi reakciókról szóló közlemények kontakt dermatitis (2, 3, 9-13, $15,16,18-20)$ és lichenoid $(5,11)$ reakciók mellett leírnak keloid jellegú elváltozást (5), illetve kontakt urticariát (21) is. A kontakt dermatitises tünetek súlyossága függ a festékkel való expozíció gyakoriságától, időtartamától és a festék PPD- illetve egyéb allergén tartalmától, koncentrációjától. $(6,14)$.

A hajfestés számos adverz reakciót válthat ki, a megjelenés igen sokszínú. Az irodalomban hajfestés által kiváltott leggyakoribb tünetek közé tartozik a kontakt dermatitis $(3,7,10,13,16,22,23)$. Az anamnézisben szereplő haj- illetve bőrszínező eljárás esetén közöltek kontakt urticariát, bullosus, vagy oedemával társuló reakciókat, illetve erythema multiforme jellegú bőrtüneteket is $(9,10$, 15, 18, 20, 25). P. Davari és mtsai hennafesték által kiváltott rhinitisről, conjunctivitisről és contact urticariáról számoltak be, ahol feltételezik a belégzéssel való szenzibilizálódás lehetôségét (21).

Keresztreakciókat tapasztalhatunk egyes PPD-vel hasonló kémiai szerkezetú vegyületek esetében. Ilyenek anyagok például: helyi érzéstelenítők (Benzocain, Procain), szulfonamidok, antrakinon típusú hashajtók, antihisztaminok, para-hidroxibenzoesav észterei, hajfestékek egyéb alkotórészei, azo- és anilinfestékek és egyes étel-adalékanyagok. Az adverz reakciók súlyossága összefügg a hajfestékekben együttesen jelenlévő, keresztreagáló vegyületekkel, melyek szinergizáló immunológiai folyamatokhoz vezethetnek $(3,9,11,12,15,16,20,22)$.

\section{A PPD szenzibilizáció epidemiológiája}

$\mathrm{Az}$ európai PPD-allergiás páciensek kétharmada nő $(12,15)$. Az expozíció a mai napig is legfőképp hajfestéken keresztül történik (90\%) (15). A bőrtünetek leggyakrabban az arcon, nyakon jelentkeznek, érintett lehet még a törzs, a kéz, a láb, illetve a karok (15). Ázsiában ezzel szemben a legtöbb PPD-érzékeny páciens férfi. Ennek oka, hogy Európában inkább a nôk festik a hajukat, általában 1-6 havonta. Ázsiában a férfiak szakállukat festik, amit heti gyakorisággal tesznek. A szenzibilizációban tehát az allergén-expozíció gyakorisága is fontos faktor (12).

Az európai egészséges populációban a PPD-szenzibilizáció mértéke 0\%-1,6\% közötti $(12,24)$, újabb adatok 2,5\%-os prevalenciáról számolnak be (25). Az európai fodrászok között akár 20\%-os gyakorisággal figyelhető meg. PPD-allergia (25). A skandináv országokban a legalacsonyabb az előfordulási gyakoriság, bár a világosabb árnyalatú hajfestékek nem tartalmaznak számottevően kevesebb allergént (26).

A dermatitises betegek körében a PPD allergia prevalenciája 4,3\% Ázsiában, 4\% Európában és 6,2\% ÉszakAmerikában. A PPD-allergia előfordulásának gyakorisága Németországban, Svédországban, Dániában és Angliában is nőtt az utóbbi években (12).

Az életkorral növekvő prevalencia az idősebb korcsoportokban gyakoribb hajfestéssel magyarázható, azonban a 14 éven aluliak körében tapasztalt igen erős PPD-reaktivitás összefüggésben állhat a fekete hennák igen magas, akár 15,7\%-os PPD tartalmával, ami közel nyolcszorosa a hajfestékekben megengedett koncentrációnak (2\%). A fiatalabb korcsoportokban gyakrabban fordulnak elő súlyos reakciók $(2,9,12)$.

Hazai kutatásokban Temesvári és mtsai egy kiemelkedően magas, 3,7\%-os PPD túlérzékenység előfordulást tapasztaltak periorbitális dermatitises betegek körében, ez valószínúleg a hajfestékek mellett szempillafesték és szemhéjtus használatával hozható összefüggésbe (18).

\section{A PPD szenzibilizáció kialakulásának elméletei}

Allergiás kontakt dermatitis kialakulásának folyamatában az allergének 500 D-nál kisebb molekulatömegú vegyületek, haptének, melyek képesek a stratum corneumon áthatolni (27). Az epidermisbe való penetrációt elősegíti a hosszú expozíció, a bőr fizikai károsodása, gyulladása és a filaggrin mutáció, mely a bőr barrierjének meggyengüléséhez vezet (28). A szenzibilizációt befolyásolja a haptének lipofilitása, kémiai szerkezete és proteinkötő-affinitása. Hapténné egy molekula metabolizáció (prohaptén elmélet) vagy egyszerú kémiai reakció (prehaptén elmélet) útján válhat. $\mathrm{Az}$ immunrendszer a hapténeket csak proteinhez való kötődésük után ismeri fel $(27,28)$.

A PPD immunogenitásához vezetô folyamatok még kutatás tárgyát képezik. Egy elmélet szerint a PPD prehaptén, a szenzibilizáció megindításához molekuláris átalakulásokon kell átesnie. Ez egyszerú kémiai reakciók által történik a levegő oxigénjén (29). Ezen autooxidációs folyamatok azonban komplexek, ezért még nem tisztázott pontosan a hapténné való átalakulás minden lépése.

A PPD stratum corneumon keresztül a dermisbe való penetrációja függ az alkalmazott körülményektől, főleg az expozíciós időtől. A hajfestést követően rendkívül kis koncentráció marad jelen, ami penetrálni tud. Ennek ellenére a betegek akár 38-97\%-a szenzibilizálódik PPD-vel hajfestés után. Ez arra enged következtetni, hogy az igen kis mennyiségben hátramaradó oxidált PPD-derivátumok nagyon erős szenzibilizáló potenciállal bírnak (28).

Több kutatás vizsgálta a PPD oxidációját $(12,30)$. A folyamat során keletkező termékek a következők: egy másik monomer struktúra (valószínúleg benzokinon-diimin), egy dimer vegyület, illetve egy trimer szerkezetú anyag, a Bandrowsky-bázis (BB). Levegő oxigénjén ugyanezen 
vegyületek voltak kimutathatóak, azonban jelentősen kisebb mennyiségben. A bőr 5,7-es pH-ján az erős immunogenitású BB a legvalószínúbb végtermék (30).

Két dermális folyamat játszik meghatározó szerepet az allergiás kontakt dermatitis PPD általi indukciójában: az autooxidáció és a PPD N-acetilációja. A PPD oxidációja dendritikus sejt (DC) aktivációhoz vezet, így az immunfolyamat indukciójához elengedhetetlen. Ezzel szemben mono- illetve diacetilált PPD nem okoz sem DC, sem pedig lymphocyta aktivációt. A bőrben a keratinocyták végzik az acetilációt PPD-n és egyéb aromás aminokon $\mathrm{N}$-acetil-transzferáz-1 enzimük segítségével. Ez a mechanizmus tehát a PPD oxidációja, így immunogénné válása ellen dolgozik.

A fenti enzimatikus út azonban telíthető, ekkor túlsúlyba kerülnek az oxidációs folyamatok, ez pedig az allergiás reakció indukciójához vezet (30).

Bőrtesztek alkalmazásánál már 0,01\%-os PPD koncentráció is elégnek bizonyult egyes esetekben reakció kiváltásához. Kutatások szerint 5 perc az a minimum expozíciós idő, mely reakciót vált ki. Ennyi idő szükséges a PPD levegôn történô autooxidációjához. Az allergén emellett kumulálódik is a bőrben az ismétlődő felvitelek során. Létezik bizonyíték arra vonatkozóan is, hogy egyes anyagok felerősíthetik a PPD szenzibilizáló kapacitását, ilyen például a tartósítószerként használt metil-dibromo-glutaronitril $(12,13)$.

A fehérjékkel való kölcsönhatáshoz, azaz a haptén-protein komplex kialakulásához, valószínúleg szükséges a PPD benzokinon-diiminná való átalakulása. Ennek az oxidációs intermediernek a jelenléte magyarázhatja a rendkívül gyakori keresztreakciókat egyéb para-amino aromás szerkezetú vegyületekkel $(12,31)$.

A bőr szenzibilizációjához szükséges továbbá a dendritikus sejtek (Langerhans sejtek, DC) aktiválása. A trimer Bandrowsky-bázis bizonyult a legerősebb DC-aktivátornak, míg a PPD jóval gyengébb indukciót hozott létre a $\mathrm{BB}$ illetve a többi oxidációs termékhez képest is. Különböző koncentrációkban a PPD-nek különböző hatásai vannak a Langerhans-sejtekre. Kis mennyiségben CD40 illetve MHCII expressziót, közepes koncentrációnál CXCL8 szekréciót, nagy dózisban pedig CD86 expressziót vált ki. Emellett magas dózisban egy erősen cytotoxikus hatás is jelentkezik (30).

Az immunfolyamat további lépéseiben T-sejt aktiváció és proliferáció figyelhető meg. Aktuális kutatások szerint a PPD autooxidációs terméke, a trimer Bandrowksy-bázis (BB) lymphocyta-proliferációt indukál mind allergiás, mind pedig egészséges egyénekben (32). PPD-specifikus lymphocyták ezzel szemben csak allergiás személyek vérében mutathatók ki. Ezt a vizsgálatot alátámasztotta az a megfigyelés is, hogy allergiás személyek vérében PPD-vel való stimuláció PPD-specifikus T-sejt klónokat eredményezett, míg egészséges személyekben ez nem történt meg. A natív PPD-vel való aktiváció mechanizmusa még nem tisztázott. Feltételezhető, hogy egy PPD-protein komplex kialakulása jelentheti az antigént (32).
Összefoglalva tehát az immunfolyamat afferens fázisának kialakulásában nélkülözhetetlen elem a PPD Bandrowsky bázissá való oxidációja, mely elegendő DC aktiválódásához, így kostimulációs szignál létrehozásához szükséges, ez pedig lényeges a szenzibilizálódás folyamatának indukciójában. Az effektor fázisban azonban már nem szükséges a BB jelenléte, allergiás személyekben natív PPD is T-sejt aktivációhoz vezet. A PPD-vel való szenzibilizálódás indukálása és kiváltása függ továbbá a PPD dózisától, a bőrrel való kontaktus időtartamától és az expozíció frekvenciájától $(30,32,33)$.

A PPD erôs immunaktivátor, azonban a populáció csupán kis hányadában alakul ki kontakt túlérzékenység oxidáló hajfesték használatát követően. Emiatt feltételezhető, hogy a hajfestékkel történő expozíciót követően az érintett személyek nagyobb része immunológiai toleranciát alakít ki (34).

\section{Szabályozás}

Németországban, Svédországban és Franciaországban tilos a PPD használata. Az Európai Bizottság 2009-es és 2013-ban módosított, kozmetikumokra vonatkozó irányelvei kimondják, hogy PPD (és PPD-szulfát) csak hajfestékekben használható, maximálisan 2\%-os koncentrációban, tilos PPD tartalmú színezôanyag használata szemöldökés szempillafestéshez, valamint direkt bőrön való alkalmazása kozmetikumokban. N-szubsztituált származékai 3\%-os koncentrációban használhatók fel oxidáló hajfestékekben. Nem ajánlják a hajszínező anyagok használatát 16 éven aluli személyeken (2, 35-37). Figyelmeztetnek arra, hogy az ideiglenes 'fekete henna' használata növelheti az allergia kialakulásának valószínûségét (37), azonban a henna tetoválások PPD koncentrációjára vonatkozóan nincs szabályozás. Az Egyesült Államokban a gyártó köteles feltüntetni, hogy az adott termék bőrtüneteket okozhat, illetve felléphet vakság is szempillafestésre való alkalmazás esetén. Az amerikai FDA (Food and Drug Administration) szerint PPD csak hajfestékekben használható, tilos bőrön történő alkalmazása $(9,22)$.

\section{Következtetés}

A parafenilén-diamin gyakori és igen erôs allergén. A szakirodalomban egyre több közlemény jelenik meg a gyermekkorban és fiatal felnőtteknél megfigyelhető PPD szenzibilizációról, mely leginkább a fekete henna használatának elterjedésével magyarázható. Vizsgálatunkban leírt, öt év epicutan tesztelt betegei között a PPD szenzibilizálódás 6,22\%-os előfordulása az európai irodalmi adatokhoz képest (átlag 4\%) magasabb. Öt év lefolyása alatt a betegek életkor szerinti megoszlása feltûnően változott. A 2007-ben megfigyelt 60-as korosztály dominanciájához képest 2011-re már a 30-as, 40-es korosztály volt többségben. Aggasztó, hogy a hajszínezés által kiváltott adverz reakciók egyre fiatalabb betegeknél léptek fel. Foglalkozás szempontjából fontos kiemelni a fodrászokat, hiszen napjainkban is ők vannak leginkább kitéve a hajszínezőkkel való expozíciónak már tanulókoruk óta. 


\section{IRODALOM}

1. DeLeo V. A.: Contact Allergen of the Year: p-Phenylenediamine. Dermatitis (2006) 17(2), 53-55.

2. Kind F., Scherer K., Bircher A. J.: Contact dermatitis to para-phenylenediamine in hair dye following sensitization to black henna tattoos - an ongoing problem. JDDG (2012) 10, 1-6.

3. Martin J., Hughes T. M., Stone N. M.: "Black henna" tattoos: an occult source of natural rubber latex allergy? Contact Dermatitis (2005) 52, 145-6.

4. Podányi B., Pónyai Gy., Németh I., Temesvári E.: Henna festés provokálta illóolaj allergia. Bôrgyógyászati és Venerológiai Szemle (2001) 78(1), 17-20.

5. Gunasti S., Aksungur V. L.: Severe inflammatory and keloidal, allergic reaction due to para-phenylenediamine in temporary tattoos. Indian journal of Dermatology, Venereology and Leprology (2010) 76, 165-7.

6. Belhadjali H., Akkari H., Youssef M., Mohamed M. Z.J.: Bullous allergic contact dermatitis to pure henna in a 3-year-old girl. Pediatric Dermatology (2011) 28, 580-1.

7. Belhadjali H., Ghannouchi N., Amri C., Youssef M., Amri M., Zili $J$. Contact dermatitis to henna used as a hair dye. Contact Dermatitis (2008) 58, 182

8. Almeida P. J, Borrego L., Pulido-Melián E., González-Díaz O.: Quantification of p-phenylenediamine and 2-hydroxy-1,4naphthoquinone in henna tattoos. Contact Dermatitis (2012) 66, 33-7.

9. Matulich J., Sullivan J.: A temporary henna tattoo causing hair and clothing dye allergy. Contact Dermatitis (2005) 53, 33-6.

10. Krasteva M., Bons B., Tozer $S$. és mtsai: Contact allergy to hair colouring products. The cosmetovigilance experience of $4 \mathrm{com}$ panies (2003-2006). European Journal of Dermatology EJD (2010) 20, 85-95.

11. Hansen D., Voutsalath M.: Contact dermatitis from a presumed allergy to paraphenylenediamine. Journal of Cosmetic Dermatology (2009) 8, 308-11.

12. McFadden J. P., Yeo L., White J. L: Clinical and experimental aspects of allergic contact dermatitis to para-phenylenediamine. Clinics in Dermatology (2011) 29, 316-24.

13. Spornraft-Ragaller P., Schnuch A., Uter W.: Extreme patch test reactivity to p-phenylenediamine but not to other allergens in children. Contact Dermatitis (2011) 65, 220-6.

14. Polat M., Dikilitaş M., Oztaş P., Alli N.: Allergic contact dermatitis to pure henna. (Internet). Dermatology Online Journal (2009) 15,15 .

15. LaBerge L., Pratt M., Fong B. G. G.: A 10 -year review of pphenylenediamine allergy and related para-amino compounds at the Ottawa Patch Test Clinic. Dermatitis (2011) 22, 332-4.

16. Sosted H., Johansen J. D., Andersen K. E.: Severe allergic hair dye reactions in 8 children. Contact Dermatitis (2006) 55 , 256.

17. Gottlöber P., Gall H., Bezold G., Peter R. U: Allergische Kontaktdermatitis bei Friseurkunden. Hautarzt (2001) 52, 401-404.

18. Temesvári E., Pónyai G., Németh I., Hidvégi B., Sas A., Kárpáti $S$.: Periocular dermatitis: a report of 401 patients. Journal of the European Academy of Dermatology and Venereology: JEADV (2009) 23, 124-8.

19. Nosbaum A., Dupin C., Nicolas J. F B.F: Severe immediate hypersensitivity and allergic contact dermatitis caused by hair dyes. Contact Dermatitis (2012) 67, 52-53.
20. Frosch P. J, Kügler K. G. J.: Patch testing with hydroxyethyl-pphenylenediamine sulfate - cross-reactivity with p-phenylenediamine. Contact Dermatitis (2011) 65, 96-100.

21. Davari P., Maibach H. I.: Contact urticaria to cosmetic and industrial dyes. Clinical and Experimental Dermatology (2011) 36, $1-5$.

22. Teixeira M., De Wachter L., Ronsyn E., Goossens A.: Contact allergy to para-phenylenediamine in a permanent eyelash dye. Contact Dermatitis (2006) 55, 92-94.

23. Pas-Wyroølak A., Wiszniewska M., Krȩcisz B. és mtsai: Contact blepharoconjunctivitis due to black henna-a case report. International Journal of Occupational Medicine and Environmental Health (2012) 25,196-9.

24. Søsted H., Agner T., Andersen K.E., Menné T.: 55 Cases of Allergic Reactions To Hair Dye: a Descriptive, Consumer Complaint-Based Study. Contact Dermatitis (2002) 47, 299-303.

25. Peiser M., Tralau T., Heidler J. és mtsai.: Allergic contact dermatitis: epidemiology, molecular mechanisms, in vitro methods and regulatory aspects. Current knowledge assembled at an international workshop at BFR, Germany. Cellular and Molecular Life Sciences (2012) 69, 763-81.

26. Kerem Yazar A. B. and C. L.: Potent skin sensitizers in oxidative hair dye products on the Swedish market. Contact Dermatitis (2009) 61, 269-275.

27. Anthony Gaspari M.: Basic mechanisms and pathophysiology of allergic contact dermatitis. Joseph Fowlers MD (Ed); UpToDate 2013; Wolters Kluwer Health (2011)

28. Pot L. M.: Penetration and haptenation of p-phenylenediamine. Contact Dermatitis (2013) 68, 193-207.

29. Lepoittevin J. P.: Metabolism versus chemical transformation or pro- versus prehaptens? Contact Dermatitis (2006) 54,73-4.

30. Aeby P., Sieber T., Beck H., Gerberick G. F, Goebel C.: Skin sensitization to p-phenylenediamine: the diverging roles of oxidation and $\mathrm{N}$-acetylation for dendritic cell activation and the immune response. The Journal of Investigative Dermatology (2009) 129, 99-109.

31. Eilstein J., Giménez-Arnau E., Duché D., Rousset F. L. J.: Synthesis and reactivity toward nucleophilic amino acids of 2,5(13C)-dimethyl-p-benzoquinonediimine. Chemical Research in Toxicology (2006) 19, 1248-56.

32. Coulter E. M., Jenkinson C., Wu Y. és mtsai: Activation of T-cells from allergic patients and volunteers by p-phenylenediamine and Bandrowski's base. The Journal of Investigative Dermatology (2008) 128, 897-905.

33. Goebel C., Coenraads P. J., Rothe H. és mtsai.: Elicitation of the immune response to $\mathrm{p}$-phenylenediamine in allergic patients: the role of dose and exposure time. The British Journal of Dermatology (2010) 163, 1205-11.

34. Rubin I.M., Dabelsteen S., Nielsen M. M. és mtsai: Repeated exposure to hair dye induces regulatory $\mathrm{T}$ cells in mice. The British Journal of Dermatology (2010) 163, 992-8.

35. Brancaccio R.: Identification and quantification of paraphenylenediamine in a temporary black henna tattoo. American Journal of Contact Dermatitis (2002) 13, 15-18.

36. European Commission Cosmetics Directive 2009/130/EC.

37. Az Európai Unió Hivatalos Lapja A BIZOTTSÁG 344/2013/EU RENDELETE (2013. április 4.) a kozmetikai termékekről szóló 1223/2009/EK európai parlamenti és tanácsi rendelet II., III., V. és VI. mellékletének módosításáról. 2013.

Érkezett: 2013. 12. 04.

Közlésre elfogadva: 2014. 01.06 